\title{
THE CONSTRUCT EQUIVALENCE OF THE JOB DIAGNOSTIC SURVEY FOR DIVERSE SOUTH AFRICAN CULTURAL GROUPS
}

\author{
M VORSTER \\ C OLCKERS \\ M A BUYS \\ P SCHAAP \\ colckers@hakuna.up.ac.za \\ Department of Human Resources Management \\ University of Pretoria
}

\begin{abstract}
The Job Diagnostic Survey (JDS) and the Job Characteristics Model (JCM) have been widely used in South African organisations. The purpose of this study was to determine whether the JDS is useful if it is applied to a particular population or to groups from highly dissimilar backgrounds.

Cultural diversity research has revealed differences between the values, attitudes and leadership styles of people from different cultural groups. In this study, Hackman and Oldham's JDS was applied to Black and White employees $(n=66)$ to determine construct equivalence for these two cultural groups. Confirmatory factor analysis confirmed that there were no significant differences between the Black and White groups tested, suggesting that the JDS could be applied to different population groups.
\end{abstract}

\section{OPSOMMING}

Die Pos-diagnostiese vraelys (JDS) en die Pos-kenmerke Model (JCM) word wydverspreid deur Suid-Afrikaanse organisasies gebruik. Die doel van hierdie studie was om te bepaal of die JDS van toepassing is op verskillende kultuurgroepe.

Navorsing rakende kultuurdiversiteit het aangetoon dat daar verskille bestaan rakende die waardes, houdings en leierskapstyle van verskillende kultuurgroepe. In hierdie studie is die (JDS) van Hackman en Oldham toegepas op Swart- en Blanke werknemers $(n=677)$ ten einde die konstruk-ekwivalensie daarvan bepaal. 'n Bevestigende faktorontleding het aangetoon dat daar geen betekenisvolle verskille bestaan tussen die Swart- en Blankegroepe wat getoets is nie. Die aanname word dus gemaak dat die JDS toegepas kan word op verskillende populasiegroepe.

South African organisations have to face the challenge of integrating and managing a very diverse workforce (Jackson, 1992). He further states that business leaders are rapidly realising that tomorrow's effective organisations will be those that have learned to manage a work force characterised by demographic diversity (Jackson, 1992).

The next logical organisational intercession that has been identified is effective demographic integration and diversity management. Effective management must involve more than finding people to fill jobs and then training them. If organisations are to continue to survive, "it is necessary to get from a heterogeneous work force the same productivity, commitment, quality, and profit which the organisation received from the old homogeneous work force without artificial programmes, standards, or barriers" (Roosevelt, 1990, p 109).

It is vital that the nature of the interactions that can develop among an organisation's employees is understood. These relationships can have an important influence on performance, turnover and innovation, especially in situations where there is substantial task interdependence among employees (Jackson, 1992).

However, in order to achieve organisational outcomes in a situation marked by demographic diversity, organisations need to discover the value of management practices that address the consequences of diversity for productivity, and the interpersonal dynamics that operate between workers (Peverett, 1995). It may be argued that, instead of containing or controlling diversity, organisations need to empower and recognise the needs of every member of the organisation so that these members can perform at the level of their highest potential. Unless this can be done, an organisation's ability to meet the performance standards of productivity, commitment, quality and profitability is likely to be hampered (McGregor, 1993).

Requests for copies should be addressed to: C Olckers, Department of Human

Resource Management, University of Pretoria, Pretoria, 0002
According to Peverett (1995), organisations need to find ways to manage their employees so that the positive consequences of both homogeneity and heterogeneity are maximised. At the same time, the negative consequences of both should be minimised. Research that shows how demographic variables and associated values and attitudes affect interpersonal dynamics and group outcomes could be particularly useful to organisations. Furthermore, creating an organisational culture that fosters awareness, value and acceptance of individual differences may in turn help to reduce racial bias and promote operative worker interaction. Research by Schuman, Steeh and Bobo (1985) suggests endorsing organisational principles and policies that address relations between diverse work groups.

The Job Characteristics Model (JCM), the accompanying Job Diagnostic Survey (JDS) and the proposed action steps for improving motivation, satisfaction and performance (Hackman \& Oldman, 1980) have been functionally used in South Africa as a revised job redesign practice (Wiesner \& Vermeulen, 1997) to address some of the critical human resources problems currently facing managers and human resources practitioners (Boonzaier \& Boonzaaier, 1994). More specifically, the model specifies the conditions under which workers tend to display motivation, satisfaction and productive behaviour.

The job characteristics theory was formulated by Hackman and Lawler (1971) as a model for job redesign. Hackman and Oldham (1974, 1980) subsequently revised the job characteristic theory and termed their refinement the "Job Characteristics Model" (JCM). Hackman and Oldham (1975) also developed a measuring instrument to validate their model, namely the "Job Diagnostic Survey" (JDS), which was revised in conjunction with the refinements of the model (Hackman \& Oldham, 1980).

Hackman and Oldham's $(1975,1976,1980)$ JCM is one of the most influential theories ever presented in the field of organisational psychology. It has served as the basis for scores of 
studies and job redesign interventions over the past two decades, and the original research has been extensively reviewed (Fried \& Ferris, 1987; Loher, Noe, Moeller \& Fitzgerald, 1985; Taber \& Taylor, 1990). Most of the research has supported the validity of the JCM, although some critiques and modifications have been proposed (Robert \& Glick, 1980; Salancik \& Pfeffer, 1978).

\section{Purpose of the JCM}

The JCM specifies the conditions under which workers tend to display motivation, satisfaction and productive behaviour. The JDS is a data-collection instrument that can be useful as part of a multiple-method diagnosis. The main uses for which the JDS is intended are the following:

- to diagnose jobs considered for redesign in order to establish the current potential of a job to enhance motivation and satisfaction;

- to identify the specific job characteristics that are most in need of enrichment; and

- to assess the readiness of employees to respond positively to improved jobs.

According to Boonzaaier et al. (2001), the JCM is based on a humanist management approach, one which aims to preserve, maintain and develop the human factor in the workplace. The individual-job congruence approach emerges from the JCM as developed by Hackman and Lawler (1971) and Hackman and Oldham (1976, 1980). The JCM attempts to specify those job characteristics that lead to favourable work outcomes such as internal motivation, job satisfaction and, effective work behaviour good performance, low absenteeism and good turnover. These favourable outcomes occur when workers experience three critical psychological states: meaningful work (they perceive their job to be important, valuable and worthwhile); experienced responsibility (they perceive their jobs as providing autonomy); and knowledge of results (they perceive their job as providing feedback about how effectively they perform their work) (Robbins, 2001). In turn, five core job characteristics that stimulate particular psychological states (skill variety, task identity, task significance, autonomy and feedback) have been identified. Workers who exhibit a high need for growth, strength, adequate knowledge, skill and satisfaction with regard to job context factors are expected to respond well to rich or high scope jobs (Hackman \& Oldham, 1980).

Several authors, for example, Porter, Lawler and Hackman (1975), Clayton (1981) and Brousseau (1983) have suggested that an individual's reaction to his or her job may be influenced not only by the properties of the job and the individual's needs, but also by the nature of the work context or the organisational "milieu" surrounding the job. Van der Vegt, Emans and Van de Bliert (1998) report that the task and outcome interdependence of team members may influence the way the JCM functions. Other variables (such as interpersonal relations, downward communication, security, remuneration and a need for independence) have also been shown to moderate the relationship of individual-job congruence with performance and/or satisfaction (Goris, Vaught \& Pettit, 2000; Clayton, 1981; Oldham, Hackman \& Pearce, 1976).

The JDS represents a comprehensive set of measurement instruments by means of which different components of the JCM can be tested empirically. The theory can thus be implemented and used in actual job enrichment programmes, including ones in South Africa (Boonzaaier et al., 2001).

The JCM and the JDS were formulated and compiled for job redesign efforts in industry. Of all the redesign theories developed to date, the JCM has generated the most research discussion (Algera, 1990, p 86). In spite of the evidence supporting the validity of the JCM and the utility of the JDS, local and international criticism has increasingly been voiced regarding particular shortcomings of both the model and the JDS. These have repeatedly been documented (Boonzaaier et al., 2001; Fried \& Ferris, 1987).

\section{Biases and equivalence of measures}

Equivalence is a key concern in cross-cultural research; meaningful cross-cultural comparisons can only be made if the data from different cultures are comparable. (Van de Vijver \& Poortinga, 1997). From a theoretical point of view, the concepts bias and equivalence are the opposite of each other; scores are equivalent when they are unbiased. Nonetheless, instead of merely treating these two concepts as opposites, the two concepts can also be treated separately because they have been associated with different aspects of cross-cultural comparisons. Equivalence is more often associated with the measurement level at which the scores obtained in different cultural groups can be compared, whereas bias indicates the presence of factors that challenge the validity of crosscultural comparisons (Van de Vijver \& Leung, 1997b).

According to Berry, Poortinga, Segall and Dasen(1992) three types of equivalence can be distinguished: structural, measurement unit, and scalar equivalence. Cross-cultural researchers are often interested in structural equivalence, as in this study, which examines the similarity between the psychometric properties of data sets from different cultures. Multidimensional scaling, factor analysis and analysis of covariance structures (structural equations) are commonly employed to study structural equivalence. Thus, if equal factor structures are obtained for various cultural groups, it can be concluded that the psychological constructs underlying the instrument are identical.

Bias is a generic term for all the noise factors that threaten the validity of cross-cultural comparisons (Van de Vijver \& Leung, 1997b). It refers to the presence of noise or systematic error in a measure and can be more formally defined as a difference between the scores of groups that have no correspondence in the domain of generalisation of the test (Poortinga, 1989). Bias is present when the meanings or implications of a test score obtained by one subgroup of test-takers are different from the meanings or implications of test scores for other test-takers (Gregory, 1996)

Three kinds of bias can be distinguished (Van de Vijver \& Leung, 1997a, 1997b; Van de Vijver \& Poortinga, 1997). The first kind is construct bias. This type of bias occurs when the construct that is being measured is not identical across cultures, or when the behaviours that constitute the domain of interest from which the items are sampled are not identical across cultures. The second type is method bias. It can result from sample incomparability, instrument characteristics, tester and interview effects, and the method of administration (Van de Vijver \& Tanzer, 1997). The third type is item bias or differential item functioning. Unlike construct and method bias, item bias refers to distortions at the item level. Biased items have a different psychological meaning across cultures (Van de Vijver \& Tanzer, 1997). Item bias also refers to anomalies at the item level, such as poor translations of items or the inapplicability of an item in a specific culture (Van de Vijver \& Leung, 1997a, 1997b). Levels of equivalence (construct, measurement unit and scalar equivalence) and the types of bias (construct, method and item bias) are related to each other. In general, the presence of bias lowers the level of equivalence. Construct bias tends to preclude any direct score comparisons and thus implies the lack of construct equivalence, measurement unit equivalence and scalar equivalence. Construct equivalence does not necessarily imply a lack of method bias or item bias. Thus a confirmation of construct equivalence does not necessarily point toward equivalence in terms of all levels of measurement or a lack of all forms of bias (Van de Vijver \& Leung, 1997b).

Factors that might influence the construct equivalence of the JDS include cultural values, attitudes (Katz \& Hass, 1988; Rokeach, 1973; Hofstede, 1980; Smircish, 1983; Goddard, 1997; Fisher, 1995) and leadership styles (Evans, Hau \& Sculli, 1989; Haire, Ghiselli \& Porter, 1966; Triandis, Brislin \& Hui, 1988; Sergiovanni, 1989; Negandhi \& Reimann, 1972; Kouzes \& Posner, 1987; England \& Lee, 1974 ) that manifest in the workplace. Cultural values, attitudes and leadership style could have an influence on the manner in which JDS items are interpreted and understood, the appropriateness of 
JDS content, the relevance of particular behaviour and the coverage of the construct in terms of domain sampling. The aim of the study is therefore to determine the construct equivalence of the JDS for Black and White employees in the industry.

\section{METHOD}

\section{Participants/respondents}

A convenience sample of 677 respondents completed the JDS. The biographical information of the respondents is set out in Table 1. The sample consisted of Blacks $(n=180)$ and Whites $(n=486)$. Approximately $49 \%$ of the respondents indicated that Afrikaans was their first language and 23\% indicated that English was their first language. Of the respondents, 27\% indicated an African language was their first language, and $1 \%$ of the respondents spoke European languages other than English as their first language.

TABLE 1

BIOGRAPHICAL INFORMATION OF THE RESPONDENTS

\begin{tabular}{|c|c|c|c|c|}
\hline & Frequency & Percentage & Valid \% & Cumulative \% \\
\hline \multicolumn{5}{|l|}{ GENDER } \\
\hline Male & 508 & 75,0 & 76,2 & 76,2 \\
\hline Female & 159 & 23,5 & 23,8 & 100,0 \\
\hline Sub-total & 667 & 98,5 & 100,0 & \\
\hline Unknown & 10 & 1,5 & & \\
\hline Total & 677 & 100,0 & & \\
\hline \multicolumn{5}{|l|}{ AGE } \\
\hline $25-30$ & 220 & 32,5 & 32,9 & 32,9 \\
\hline $31-49$ & 393 & 58,0 & 58,9 & 91,8 \\
\hline $50+$ & 54 & 8,0 & 8,1 & 100,0 \\
\hline Sub-total & 667 & 98,5 & 100,0 & \\
\hline Unknown & 10 & 1,5 & & \\
\hline Total & 677 & 100,0 & & \\
\hline \multicolumn{5}{|l|}{ CULTURAL GROUP } \\
\hline Black & 180 & 26,6 & 27,0 & 27,0 \\
\hline White & 486 & 71,8 & 73,0 & 100,0 \\
\hline Sub-total & 666 & 98,4 & 100,0 & \\
\hline Unknown & 11 & 1,6 & & \\
\hline Total & 677 & 100,0 & & \\
\hline \multicolumn{5}{|l|}{ LANGUAGE } \\
\hline Afrikaans & 328 & 48,4 & 49,1 & 49,3 \\
\hline English & 150 & 22,2 & 22,5 & 71,7 \\
\hline isiNdebele & 11 & 1,6 & 1,6 & 73,4 \\
\hline siSwati & 8 & 1,2 & 1,2 & 74,6 \\
\hline isiXhosa & 16 & 2,4 & 2,4 & 76,9 \\
\hline isiZulu & 33 & 4,9 & 4,9 & 81,9 \\
\hline Sepedi & 39 & 5,9 & 5,8 & 87,7 \\
\hline Sesotho & 20 & 3,0 & 3,0 & 90,7 \\
\hline SeTswana & 28 & 4,1 & 4,2 & 94,9 \\
\hline TshiVenda & 11 & 1,6 & 1,6 & 96,6 \\
\hline xiTsongo & 16 & 2,4 & 2,4 & 99,0 \\
\hline Other & 7 & 1,0 & 1,0 & 100,0 \\
\hline Sub-total & 668 & 98,7 & 100,0 & \\
\hline Unknown & 9 & 1,3 & & \\
\hline Total & 677 & 100,0 & & \\
\hline \multicolumn{5}{|l|}{ QUALIFICATIONS } \\
\hline Lower than Std 8 & 96 & 14,2 & 14,5 & 18,2 \\
\hline Matric & 222 & 32,8 & 33,3 & 47,9 \\
\hline Diploma/Degree & 289 & 42,7 & 43,4 & 91,3 \\
\hline Honours & 35 & 5,2 & 5,3 & 96,5 \\
\hline Masters & 22 & 3,2 & 3,3 & 99,8 \\
\hline Doctorate & 1 & 0,1 & 0,2 & 100,0 \\
\hline Sub-total & 666 & 98,4 & 100,0 & \\
\hline Unknown & 11 & 1,6 & & \\
\hline Total & 677 & 100,0 & & \\
\hline
\end{tabular}

Approximately $33 \%$ of the respondents were 30 years and younger, and 59\% were between 31 years and 49 years of age. Only $8 \%$ were over 50 years old.

Of the respondents, $52 \%$ had a qualification from a tertiary institution and $33 \%$ had matriculated.

\section{Measuring instrument}

The measurement instrument used was the JDS developed by Hackman and Oldham (1980). The JDS consists mainly of job characteristics and personal outcomes. There are 15 items (see Table 2) that are scored in each section of the revised JDS. The items of the JDS are endorsed on a seven-point Likert scale, anchored at the extreme values of 1 and 7 . Previous studies have indicated a clear and well-defined simple structure for the following five job characteristics: skill variety, task variety, task significance, feedback and autonomy (Boonzaaier et al., 2001).

TABLE 2

ITEM AGGREGATES FOR THE JDS

\begin{tabular}{lccc}
\hline Job characteristics (15 items) & & & \\
Skill variety & 3 & 6 & 9 \\
Task identity & 2 & 10 & 12 \\
Task significance & 4 & 11 & 15 \\
Autonomy & 1 & 8 & 14 \\
Feedback & 5 & & 13 \\
\hline Personal outcomes (15 items) & 18 & 20 \\
Internal work motivation & 16 & 30 & \\
& 27 & 19 & 21 \\
General job satisfaction & 17 & 29 & \\
& 28 & 24 & 25 \\
Growth satisfaction & 23 & & \\
\hline
\end{tabular}

\section{Statistical analysis}

Descriptive statistics in respect of the JDS scale items were calculated for Blacks and Whites separately.

The Structural Equation Modeling (SEM) process was used, because it focuses on two steps: validating the measurement model and fitting the structural model (Garson - online). Kline (1998) urges SEM researchers always to test the pure measurement model underlying a full structural equation model first, and only if the fit of the measurement model is found to be acceptable, to proceed to the second step of testing the structural model by comparing its fit with that of different structural models (models generated by trimming or building). For the purpose of this study, confirmatory factor analysis (CFA) was used for the validation of the measurement model. CFA seeks to determine whether the number of factors and the loadings of measured (indicator) variables conform to what is expected on the basis of preestablished theory. CFA may be used to confirm that the indicators sort themselves into factors corresponding to how well the indicators have been linked to the latent variables (Garson - online).

The measurement model was evaluated like any other SEM model, using goodness-of-fit measures. Goodness-of-fit tests determine whether the model being tested should be accepted or rejected. The EQS program (Bentler, 1989) was used for all the SEM procedures, with maximum likelihood (ML) estimation. The EQS prints ten different goodness-of-fit measures.

Jaccard and Wan $(1996$, p87) recommend the use of at least three goodness-of-fit tests. Kline (1998, p130) recommends at least four tests. The following indexes of model fit were used: the Non-Normed fit index (NNFI) (Bentler \& Bonnett, 1980), 
the comparative fit index (CFI) (Bentler, 1989, 1990) the Incremental Fit Index (IFI) (Bollen, 1989) and the Root Mean Square Error of Approximation (RMSEA). An NNFI close to 1 indicates a good fit. By convention, the IFI should be equal to or greater than 0.90 for the model, to be accepted, but it can be greater than 1.0 for the model to be accepted. The RMSEA by convention indicates a good fit if it is less than or equal to 0.08. Hu and Bentler (1999) have suggested that the RMSEA be smaller than, or equal to, 0.06 as a cut-off for a good model fit. RMSEA is a popular measure of fit and works with a better venue of independence (Garson-online). The chances of obtaining a non-significant chi-square become extremely small with large sample sizes. The ratio of chi-square to degrees of freedom has been proposed, although it appears to suffer from arbitrary standards of interpretation (Kelloway, 1998). The CFI, the NNFI and the IFI are considered to be relatively robust in respect of the effects of sample size (Bentler, 1990).

Preliminary single group confirmatory factor analysis was conducted as a measure to test to which extent the data fits the proposed measurement model in respect of the two cultural groups. The necessity of determining the model fit separately for each of the cultural groups before alternative hypotheses could be investigated has already been addressed in the multiple-group context by Byrne, Shavelson and Muthén (1989). If a model fits badly in a one-group analysis, it is likely that the model will not fit when it forms part of a larger multisample analysis (Bentler, 1995).

Measurement invariance may be defined with varying degrees of stringency, depending on which parameters are constrained to be equal. One can test for invariance on a number of factors: for invariant factor loading; and for invariant structural relations (arrows) between the latent variables. While it is possible also to test for the equality of error variances and covariances across groups, "the testing of equality constraints bearing on error variances and covariance's is now considered to be excessively stringent..." (Byrne, 2001, p 202).

A set of hierarchically nested models that successively increased the number of equality constraints was used to test the equivalence of the constructs in respect of the Black and White groups. The constraints were imposed in the sequence proposed by Van den Berg and Self (1993), starting with the equality of the number of factors, followed by the equality of factor covariances and ending with the equality of factor loadings. The incremental change in the chi-square with each constraint that is imposed provides an indication of the extent to which the constraints could be considered reasonable for the two groups. The chi-square, CFI, NNFI, IFI and RMSEA statistics were used as overall goodness-of-fit indices for the nested models.

A chi-square difference test was applied to determine whether the difference between the models was significant. If the constrainedequal model is the same as the unconstrained multi-group model and the difference of the chi-square is not significant, it is possible to conclude that the model does apply across the groups tested and does display measurement invariance.

\section{RESULTS}

The descriptive statistics for the JDS scales for the Black and White groups are set out in Table 3. The variability of the means, standard deviation, skewness and kurtosis reflects how the participants responded to the different scales. The variability indicates that the data which were collected and analysed were normally distributed. It is clear from Table 3 that the Black and White groups obtained homogeneous scores relative to skill variety, task identity, task significance, autonomy and feedback.
TABLE 3

DeSCRIPTIVE STATISTICS FOR THE JDS

\begin{tabular}{lrccr}
\hline BLACK GROUP $(\mathbf{n}=\mathbf{1 8 0})$ & & & & \\
\hline & Mean & SD & Skewness & Kurtosis \\
Skill variety & 5,054 & 1,334 & $-0,704$ & $-0,042$ \\
Task identity & 16,328 & 3,216 & $-0,743$ & 3,72 \\
Task significance & 5,867 & 1,091 & $-0,878$ & 0,257 \\
Autonomy & 4,835 & 1,278 & $-0,401$ & $-0,067$ \\
Feedback & 5,435 & 1,244 & $-0,848$ & 0,218 \\
\hline WHITE GROUP $(\mathbf{n}=487)$ & & & & \\
\hline & Mean & SD & Skewness & Kurtosis \\
Skill variety & & & & \\
Task identity & 5,144 & 1,167 & $-0,904$ & 1,161 \\
Task significance & 15,635 & 3,317 & $-0,727$ & 0,8 \\
Autonomy & 5,434 & 1,069 & $-0,892$ & 1,203 \\
Feedback & 5,055 & 1,105 & $-0,848$ & 0,845 \\
\hline
\end{tabular}

A confirmatory factor analysis was done on the total group to determine whether the model fitted the data. As indicated in Table 4, the CFI, NNFI and IFI values were $0.918,0.893$ and 0.919 respectively. A value of 0.90 is considered to be a good fit for all the above fit indices (Bentler, 1990; Bentler \& Bonnett, 1980; Steiger, 1995). In this study, the RMSEA had a value of 0.072 . Steiger (1995) considers RMSEA values less than 0.10 as an acceptable model fit.

TABLE 4

FIT INDICES FOR THE POOLED SAMPLE

\begin{tabular}{lc}
\hline Model & Pooled sample \\
\hline Chi-square & 350,866 \\
(df) & 80 \\
NNFI & 0,893 \\
CFI & 0,918 \\
IFI & 0,919 \\
RMSEA & 0,072 \\
\hline
\end{tabular}

$\mathrm{P} \leq 0.001$

The chi-square was 350.866 with $80 \mathrm{df}(\mathrm{p}=0.001)$ for the total group. The chi-square/df ratio is 4.38. Carmines and McIver (1981, p 800) claim that the relative chi-square should be in the 2:1 to 3:1 range for an acceptable model. However, ratios between two and five have also been accepted. Given the large sample size, it would be incorrect to conclude a poor fit based on the significance of the chi-square indices. Thus the chi-square ratio of 4.38 can be interpreted as indicating a good fit (Kelloway, 1998).

The structural equation models for the five domains underlying the JDS for the total group, the Black and White groups respectively are given in Figures 1,2 and 3. The latent variables have been allowed to correlate with one another.

Table 5 indicates that the Job Characteristics Model had a more acceptable goodness of fit index for the White than for the Black group. The CFI, NNFI and IFI for the Black group were 0.872, 0.832 and 0.875 respectively. The RMSEA was 0.086 and the chisquare/df ratio was 2:3 for the Black group. For the White group, the CFI was 0.913 , the NNFI was 0.885 and the IFI was 0.913 . The RMSEA for the White group was 0.079 and the chi-square/df ratio was $3: 5$, indicating a better fit than the fit of the model for 
the Black group. The significance of the observed differences in the model fit indices was investigated further by means of multiple-group analysis.

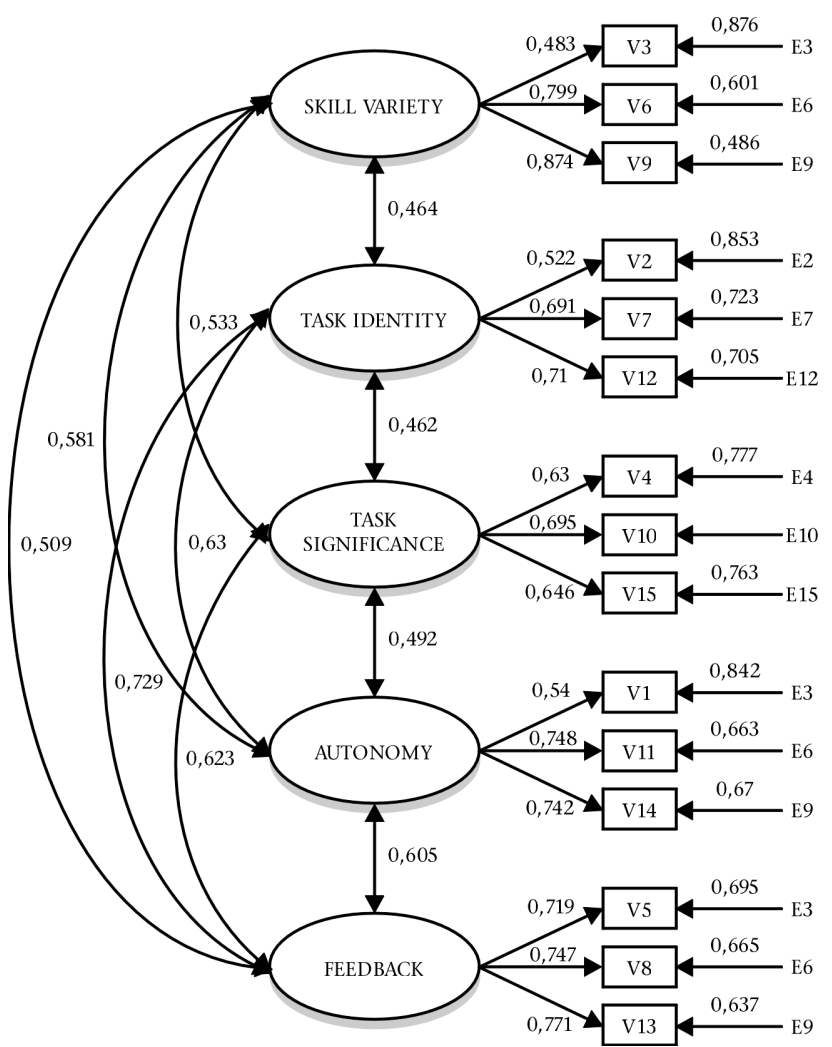

Figure 1: Standardised estimated parametres of the JDS for the total group

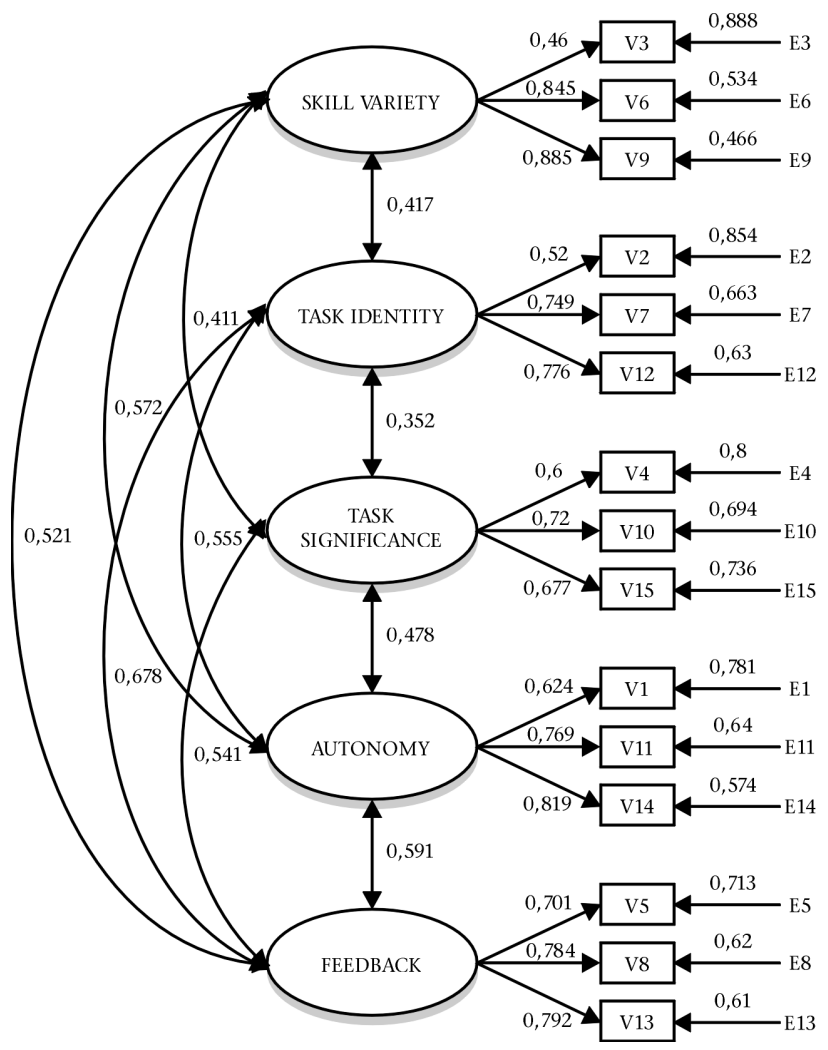

Figure 2: Standardised estimated parametres of the JDS for the white group

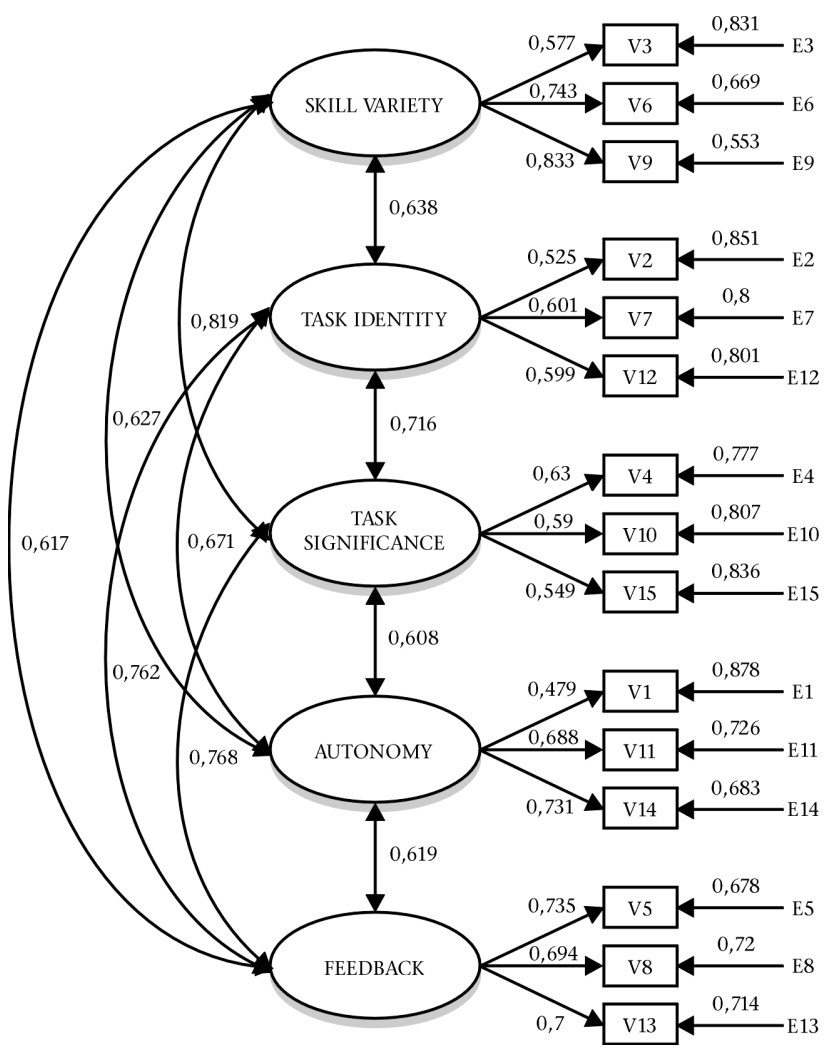

Figure 3: Standardised estimated parametres of the JDS for the black group

TABLE 5

FIT INDICES FOR THE BLACK AND WHITE GROUPS

\begin{tabular}{lcc}
\hline Model & & \\
\hline & Black $(\mathrm{n}=180)$ & White $(\mathrm{n}=415)$ \\
Chi-Square & 184,177 & 280,087 \\
(df) & 80 & 80 \\
NNFI & 0,832 & 0,885 \\
CFI & 0,872 & 0,913 \\
IFI & 0,875 & 0,914 \\
RMSEA & 0,086 & 0,079 \\
\hline
\end{tabular}

$\mathrm{P}=0.001$

Table 6 represents the results of the multi-group analysis. The CFI, NNFI and IFI for the equal factor model were 0.902, 0.871 and 0.903 respectively. The RMSEA was 0.057 and the chi-square/df ratio was 2:39 for the equal factor model. Thus, the fit indices point toward the equivalence of the factor model for the Black and White groups. The series of hierarchically nested models indicated statistically nonsignificant changes in chi-square values for all the model constraints that were set (equal factor covariance, $\Delta \chi^{2}(10)=$ $23.865 \mathrm{p}=0.05$ and equal factor loading, $\Delta \varkappa^{2}(15)=21,57, \mathrm{p}$ $=0.05)$ with regard to the Black and White groups. Thus, the changes in the NNFI, CFI, IFI and RMSEA values for each constraint that was set can be considered insignificant. Overall, the results provided convincing evidence of the equivalence of the structural model of the JDS in respect of the Black and White groups. 
TABLE 6

RESULTS OF THE MULTIPLE GROUP ANALYSIS

\begin{tabular}{|c|c|c|c|c|c|c|c|c|}
\hline MODEL & $x^{2}$ & df & $\ddot{A} x^{2}$ & $\ddot{\mathrm{A}} \mathrm{df}$ & CFI & NNFI & IFI & RMSEA \\
\hline \multicolumn{9}{|c|}{ Nested models } \\
\hline $\begin{array}{l}\text { Equal factor } \\
\text { model }\end{array}$ & $464.264^{* *}$ & 160 & NA & NA & 0.902 & 0.871 & 0.903 & 0.057 \\
\hline $\begin{array}{l}\text { Equal factor } \\
\text { covariances }\end{array}$ & 488.129 * * & 170 & 23.865 & 10 & 0.877 & 0.873 & 0.899 & 0.057 \\
\hline $\begin{array}{l}\text { Equal factor } \\
\text { loadings }\end{array}$ & 509.708 * * & 185 & 21.579 & 15 & 0.895 & 0.881 & 0.896 & 0.055 \\
\hline
\end{tabular}

\section{DISCUSSION}

The research results confirm the equivalence of the structural model of the JDS in respect of the Black and White cultural groups that were included in the study. In terms of the constructs measured, it is evident from the study that there were no significant differences between the Black and White groups who completed this survey. Thus, proof does exist that the JDS measure could be used across cultural groups as part of the process of implementing and utilising the JDS theory for job enrichment programmes in South Africa.

According to the results, cross-cultural differences that might exist such as differences in values, attitudes and leadership style did not seem to have an influence on the functioning of the scale in terms of the construct measures. In more specific terms, it can be assumed that the above-mentioned culturally loaded factors did not have an influence on the manner in which JDS items were interpreted and understood, the appropriateness of JDS content, the relevance of behaviour and the coverage of the construct in terms of domain sampling for the particular sample group.

Limitations and recommendations of the study

- Structural equivalence does not imply that both the origin and the measurement unit of the instrument are identical. It is primarily based on similarity in correlations across a variety of cultures. Correlations are not affected by linear transformations of the variables. Therefore, similar factor loadings can arise from scales of different origins and using different measurement units.

- Measurement unit equivalence and scalar equivalence were not taken into consideration in this study and may be further investigated for similar sample groups in another study. When the scores of two cultural groups are compared, it is possible that the unit of measurement is identical, but that the scales do not have a common origin. In the case of measurement unit equivalence, differences between two scores can be compared both within and across cultures, while the scores themselves can only be compared within cultures. It can be ascertained that scores show not only an identical unit of measurement, but also a common origin, scalar equivalence or full score comparability is said to have been obtained. Scalar equivalence allows the comparison of the scores obtained, for both with and across cultural groups.

- As discussed, according to Van de Vijver and Leung (1997), there are three kinds of bias: construct, method and item bias. This study only focused on construct bias. Construct bias occurs if the construct measured is not identical across cultural groups. It was evident from the study that there were no significant differences between the cultural groups who completed the survey. However method bias (this refers to problems deriving from instrument characteristics) and item bias (this refers to measurement artifacts at item level) have not been taken into consideration.

- Another limitation of the study is the fact that the JDS is a relatively short survey with only 15 items for five underlying constructs, which could be a reason why the cultural differences are not pertinently observable. An expansion of the questionnaire is recommended.

\section{REFERENCES}

Algera, J.A. (1990). The Job Characteristics Model of work motivation revisited. In H. Kleinbeck, H. Quast,H. Thierry \& H. Hacker. (Eds.). Work Motivation. London: Lawrence Erlbaum.

Bentler, P.M. \& Bonnett, D.G. (1980). Significance tests \& goodness-of-fit in the analysis of covariance structures. Psychological Bulletin, 88, 588-606.

Bentler, P.M. (1989). EQS structural equations program: Manual. Los Angeles: BMDD Statistical Software.

Bentler, P.M. (1990). Comparative fit indexes in structural models. Psychological Bulletin, 107, 238-246.

Berry, J.W., Poortinga, Y.H., Segall, M.H. \& Dasen, P.R. (1992). Cross-cultural psychology. Research and applications. Cambridge: Cambridge University Press.

Bollen, K. A. (1989). Structural equations with latent variables. New York: Wiley.

Boonzaier, B. \& Boonzaier, M. 1994. The job diagnostic survey: A functional tool for South African managers. South African Journal of Business Management, 25 (3), 101-109.

Boonzaaier, B., Ficker, B. \& Rust, B. (2001). A review of research on the job characteristics model and the attendant job diagnostic survey. South African Journal of Business Management, 32 (1), 11-34.

Brousseau, K.R. (1983). Toward a dynamic model of job-person relationships: Findings, research questions, and implications for work system design. Academy of Management Review, 8, 33- 45 .

Byrne, B. (2001). Structural equation modelling with Amos. Rahwah, NJ: Lawrence Erlbaum.

Byrne, B.M., Shavelson, R.J. \& Muthén, B. (1989). Testing for the equivalence of factor covariance and mean structures: The issue of partial invariance. Psychological Bulletin, 105, 456-466.

Carmines, E.G. \& McIver, J.P. (1981). Analyzing models with unobserved variables: Analysis of covariance structures. Thousand Oaks, CA: Sage.

Clayton, S.H. (1981). Moderators of the relationship between individual-task-structure.

England, G.W. \& Lee, R. (1974). The relationship between managerial values and managerial successes in the United States, Japan, India and Australia. Journal of Applied Psychology, 59, 411-419.

Evans, W.A., Hau, K.C. \& Sculli, D. (1989). A cross-cultural comparison of managerial styles. Journal of Management Development, 8 (3), 5-13.

Fisher, J. (1995). Contingency based research on management on management control systems: categorisation by level of complexity. Journal of Accounting Literature, (14), 24-53.

Fried, Y. \& Ferris, G.R. 1987. The validity of the job characteristics model: A review and meta-analysis. Personnel Psychology, 40, 287-322.

Garson, G.D. Online. Statsnotes: An Online Textbook. PA 765. Available from http://www2.chass.ncsu.edu/garson/pa765/ statnote.htm. [Accessed 26 May 2002 ].

Goddard, A. (1997). Organizational culture and budget related behaviour: A comparative contingency study of three local government organizations. The International Journal of Accounting, 32 (1), 79-97.

Goris, J., Vaught, B. \& Pettit, J. (2000). Effects of communication direction on job performance and satisfaction: A moderated regression analysis. The Journal of Business Communication, 37 (4), 348-368 
Gregory, R.J. (1996). Psychological testing history, principles and applications. $2^{\text {nd }}$ Ed. Needham Heights, MA: Allyn \& Bacon.

Hackman J. R. \& Lawler E. E. (1971). Employee reactions to Job characteristics. Journal of Applied Psychology Monograph, 55, 259-286

Hackman, J.R. \& Oldham, G.R. (1974). The job diagnostic survey: An instrument for diagnosing the motivational potential of jobs. Technical Report no. 4.

Hackman, J. \& Oldham,G. (1975). Development of the job diagnostic survey. Journal of Applied Psychology, 60 (2), $159-170$

Hackman, J.R. \& Oldham, G.R. (1976). Motivation through the design of work: Test of a theory. Organizational Behaviour of Human Performance, 16 (2), 250-279.

Hackman, J.R. \& Oldham, G.R. (1980). Work redesign. Phillipines: Addison- Wesley.

Haire, M., Ghiselli, E. \& Porter, L. (1966). Managerial thinking: An international study. New York: Wiley.

Hofstede, G. H. (1980). Cultural consequences: International differences in work-related values. Beverly Hills, CA: Sage.

Hu, L. \& Bentler, P. M. (1999). Cutoff criteria for fit indexes in covariance structure analysis: Conventional criteria versus new alternatives. Structural Equation Modeling, 6 (1), 1-55.

Jaccard, J. \& Wan, C. K. (1996). Lisrel approaches to interaction effects in multiple regression. Thousand Oaks, CA: Sage.

Jackson, S.E. (1992). Team composition in organizational settings: Issues in managing an increasingly diverse workforce. In Worchel, S., Wood, W. \& Simpson, J.A. (Eds.). Group process and productivity, 139-173. Newbury Park, CA: Sage.

Katz, I. \& Hass, R.G. (1988). Racial ambivalence and American value conflict: Correctional and priming studies of dual cognitive structures. Journal of Personality and Social Psychology, 55 (6), 893-905.

Kelloway, E.K. (1998). Using LISREL for structural equation modeling: A Researcher's guide. Thousand Oaks, CA: Sage.

Kouzes, J.M. \& Posner, B.Z. (1987). The leadership challenge: How to get extraordinary things done in organisations. San Francisco: Jossey-Bass.

Loher, B., Noe, R., Moeller, N. \& Fitzgerald, M. (1985). A metaanalysis of the relation of job characteristics to job satisfaction. Journal of Applied Psychology, 70, 280-289.

McGregor, A. (1993). A holistic approach to affirmative action. In Innes, D.M. \& Perold, H (Eds.). Reversing discrimination: affirmative action in the workplace, Cape Town: Oxford University Press.

Miner, J.B. (1980). Theories of organizational behaviour. Hinsdale: Dryden Press.

Negandhi, A.R.l. \& Reiman, B.C. (1972). A contingency theory of organisation re-examined in the context of a developing country. Academy of Management Journal, 15, 137-146.

Peverett, M.R. (1995). Values and leadership in the management of organisational diversity. Masters dissertation, University of the Witwatersrand, Johannesburg.
Poortinga, Y.H. (1989). Equivalence of cross-cultural data: an overview of basic issues, International Journal of Psychology, $24,737-756$

Porter, L. W., Lawler, E. E. \& Hackman, J. R. (1975). Behavior in organizations. New York: McGraw-Hill.

Robbins, S.P. (2001). Organisational behaviour. 9th Edition. Englewood Cliffs, NJ: Prentice Hall.

Robert, K .H. \& Glick, W. (1980). The job characteristics approach to task design: A critical review. Journal of Applied Psychology, 66 (2) 193-217.

Rokeach, M. (1973). The nature of human values. New York: Free Press.

Roosevelt, T.R. (1990). From affirmative action to affirming diversity. Harvard Business Review, March-April, 107-117.

Salancik, G. \& Pfeffer, J. 1978. A social information processing approach to job attitudes and task design. Administrative Science Quarterly, 23, 224-253.

Schuman, H., Steeh, C. \& Bobo, L. (1985). Racial attitudes in America. Cambridge, MA: Harvard University Press.

Sergiovanni, T.G. (1989). Leadership as a cultural expression. In Ott, J.S. (Ed.). Classic readings in oganisational behaviour. Pacific Grove, CA: Brooks/Cole.

Smircish, L. (1983). Concepts of culture and organizational analysis. Administrative Science Quarterly, September, 339-358.

Steiger, J.H. (1995). Manual to Statistica - SEPATH. Tulsa, OK Statsoft.

Taber, T \& Taylor, E. (1990). A review and evaluation of the psychometric properties of the job diagnostic survey. Personnel Psychology, (43), 467-500.

Triandis, H.C., Brislin, R. \& Hui, C.H. (1988). Cross cultural training across the individualism-collectivism divide International Journal of Intercultural Relations, 12, 269-289.

Van den Berg, R. J. \& Self, R. M. (1993). Assessing newcomers' changing commitments to the organization during the first 6 months of work. Journal of Applied Psychology, 78, 557-568.

Van der Vegt, G., Emans, B. \& Van de Bliert, E. (1998). Motivating effects of task and outcome interdependence in work teams. Group \& Organization Management, 23, 124-143.

Van de Vijver. F.J.R. \& Leung, K. (1997a). Methods \& data analysis of comparative research. In Berry, J.W., Poortinga, Y.H. \& Pandrey, J. (Eds.). Handbook of cross-cultural psychology (2nd Edition). Boston: Allyn \& Bacon.

Van de Vijver, F.J.R. \& Leung, K. (1997b). Methods \& data analysis for cross-cultural research. Newbury Park, CA: Sage.

Van de Vijver, F. J.R. \& Poortinga, Y.H. (1997). Towards an integrated analysis of bias in cross-cultural assessment. European Journal of Psychological Assessment, 13, 29-37.

Van de Vijver, F.J.R. \& Tanzer, N.K. (1997). Bias \& equivalence in cross-cultural assessment: an overview. European Review of Applied Psychology, 47 (4), 263-279.

Wiesner, R \& Vermeulen, L.P. 1997. Revised job design practices for future South African organisations. South African Journal of Economic and Management Sciences, 12, 175-196. 


\section{Jopie van Rooyen \& Partners SA (Pty) Ltd}

Sub-Saharan Africa Test Distributors, Publishers and Consultants

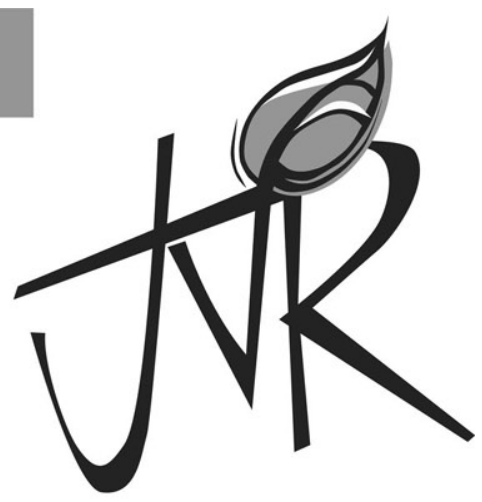

5
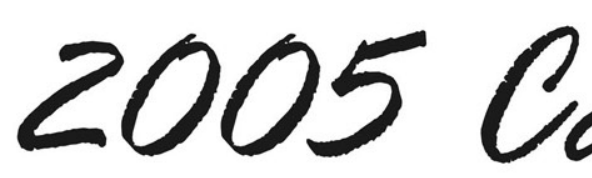

atalogn

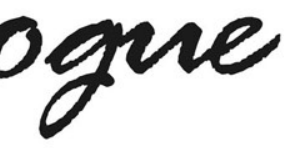

JvR announces that their

new catalogue is now available.

Contact them on

(011) 7813705 (Johannesburg)

or (021) 9130541 (Cape Town),

or e-mail them at info@vanrooyen.co.za

to receive a complimentary copy.

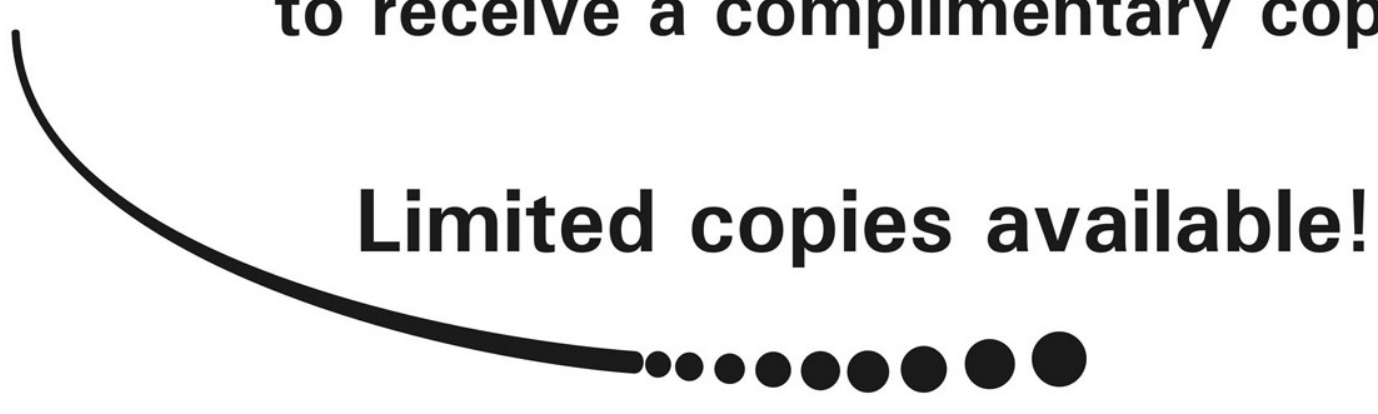

Please diarise 22 April (Johannesburg)

and 2 September (Cape Town)

for our 2005 Open Days.

For further information, visit the Johannesburg/Cape Town offices, or logon to our website www.vanrooyen.co.za. 